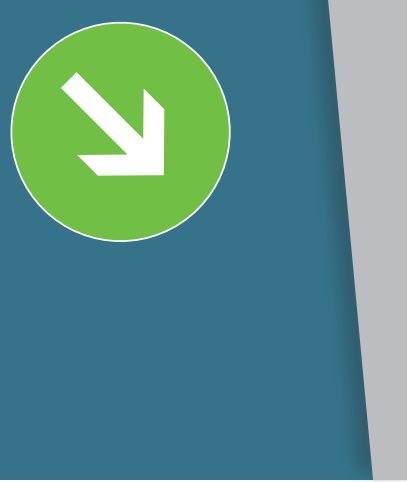

\title{
ВЫСОКОСКОРОСТНЫЕ ПЛАСТИНЫ И ФРЕЗЫ ДЛЯ АВИАЦИОННОГО АЛЮМИНИЯ
}

\section{Александр МоСквитИн}

Существенным преимуществом высокоскоростной обработки является обусловленная значительным снижением сил резания возможность высокопроизводительного фрезерования тонкостенных деталей, что особенно важно при изготовлении деталей летательных аппаратов из алюминиевых сплавов.

К области высокоскоростной обработки алюминиевых сплавов относится диапазон скоростей резания от 1200 до 7000 м/мин. Процесс фрезерования в области указанных скоростей имеет специфические особенности, накладывающие определенные ограничения на конструкцию режущего инструмента. Фрезы, используемые для обработки со скоростью выше 1200 м/мин, должны иметь повышенную точность по радиальному биению, малый дисбаланс и конструкцию, гарантирующую безопасность эксплуатации на высоких частотах вращения. Как правило, требуется динамическая балансировка такого инструмента.

В данной статье рассматриваются новые концевые и торцовые фрезы СКИФ-М для высокоскоростной обработки алюминиевых сплавов диаметром режущей части от 25 до 125 мм (рис. 1).

Фрезы оснащаются твердосплавными пластинами типа XEHX1705...FR с длиной режущей кромки 17 мм (рис. 2) с широким диапазоном радиусов при вершине. Группа новых пластин включает 10 стандартных радиусов : 0,$2 ; 0,4 ; 0,8 ; 1,2 ; 1,6 ; 2,0 ; 2,5 ; 3,0 ; 4,0$ и 5,0 мм. Уникальное алмазоподобное покрытие пластин гарантирует многократное увеличение стойкости режущего

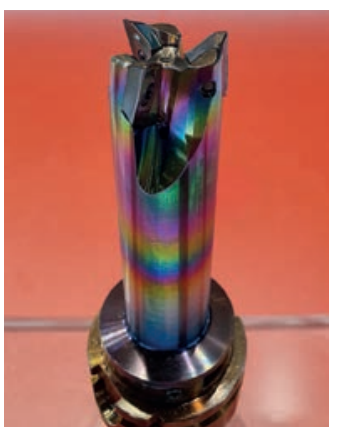

PUC. 1.

Новая концевая высокоскоростная фреза

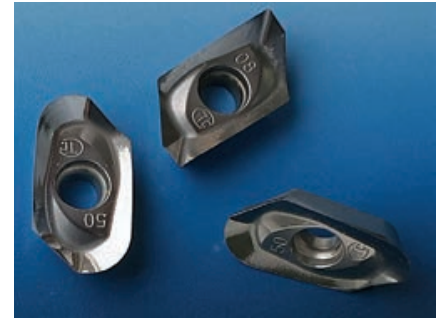

Puс. 2. Новые пластины СКИФ-М для алюминия при фрезеровании карманов. Так при использовании торцовой фрезы диаметром 50 мм угол косого врезания фрезы с пластинами XE17 почти в два раза больше максимального значения фрез СКИФ-М 2018 года, оснащаемых пластинами XD19. А величина вертикального врезания для фрезы того же размера больше уже в 2,5 раза (см. табл. 1). В отличие от всех известных конструкций аналогичного инструмента в единый стандартный корпус фрезы можно устанавливать пластину любого радиуса от 0,2 до 5,0 мм без дополнительной доработки корпуса, что сокращает номенклатуру применяемых корпусов фрез у заказчика, снижает затраты и повышает мобильность производства.

\section{Таблица 1. Параметры фрез СКИФ-М}

\begin{tabular}{|c|c|c|c|c|}
\hline & Пластина & $\begin{array}{l}\text { Глубина } \\
\text { резания, } \\
\text { мм }\end{array}$ & $\begin{array}{l}\text { Угол } \\
\text { косого } \\
\text { вреза- } \\
\text { ния, }^{\circ}\end{array}$ & $\begin{array}{l}\text { Глубина } \\
\text { осевого } \\
\text { вреза- } \\
\text { ния, мм }\end{array}$ \\
\hline $\begin{array}{l}\text { Конструкция фрез } \\
\text { СКИФ-М до } 2018 \text { г. }\end{array}$ & $\begin{array}{l}\text { XDHT } \\
\text { 190408FR-AL }\end{array}$ & 18 & 4 & 2,5 \\
\hline $\begin{array}{l}\text { Новая конструкция } \\
\text { фрез СКИФ-М } 2019 \text { г. }\end{array}$ & $\begin{array}{l}\text { XEHX } \\
\text { 170508FR-AL }\end{array}$ & 16,8 & 7,5 & 6,5 \\
\hline
\end{tabular}

Исполнение концевых фрез с центральным расположением пластины, перекрывающей ось фрезы, предоставляет возможность выполнять в детали неглубокие отверстия без предварительного засверливания и многократно повышает производительность при обработке глубоких карманов сечением до 80 мм.

тельной обработки деталей самолетов со скоростью резания до 5000 м/мин при подаче до 0,45 мм/зуб.

Значительные преимущества новые фрезы показывают
МоСКВитИн Александр Александрович -

кандидат технических наук, генеральный директор 000 «СКИФ-М» 


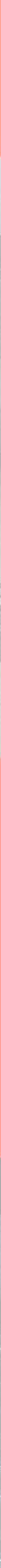

